\title{
PSYCHF.
}

\section{ON THE OCCURRENCE OF ORGANS PROBABLY OF TASTE IN THE EPIPHARYNX OF THE MECAPIERA (PANORPA AND BOREUS).}

\author{
BY ALPHEUS SPRING PACKARE, PROVIDENCE, R. I.
}

From the observations of Meinert, Forel, Kraepelin and Will anatomical and experimental proofs have been afforded of the existence of organs of taste on the parts of the maxillae near the mouth, and also on the lingua or "tongue" of-ants, wasps and bees; while Lubbock, in his recent excellent work "On the senses," etc. of animals, claims that the organs discovered by Wolff in the mouth-parts of the lower hymenoptera, e.g., tenthredinidae, evaniidae, chalcididae and proctotrupidae are also those of taste.

I have observed organs such as $\mathrm{Will}^{1}$ describes and figures (his figs. I, 8, 8a, 9 , I I, I6, etc.), which he calls "'geschmacksbecher" and Lubbock translates as " taste-cups," in the mounted preparations of the mouth-parts of the honey bee and a species of Bombus, kindly loaned me by Mr. N. N. Mason, of Providence. In the honey bee they are most abundant in the paraglossae situated at the base of the tongue and at

\footnotetext{
1 Das geschmacksorgan der insecten. (Zeitschrift für wissensch . zool., 1885 v. 42, p. 674.)
}

the end of the furrow. Each paraglossa bears about 22-27 taste-cups, in my specimen 22 on the left, and 27 on the right paraglossa ; on the inside, near the base of each labial palpus, and opposite the middle of the paraglossae are situated a group of exactly similar tastecups, which are, however, rather like pegs than sunken cups or pits; they are protected in front by a few defensive spinules; and there are about 30 on each side.

In the Bombus, the left paraglossa bears about 28 taste-pegs arranged in irregular oblique rows; on the right are 28. On the base of the labial palpi, the taste-cups are less peg-shaped, more like cups, the rods being shorter and smaller while the rim of the cup is more marked. The terminal joint of the maxillae of Vespa maculata have no taste-cups, but about 35 taste-rods, which are much longer than those of Vespa vulgaris figured by Will.

I have also observed the taste-cups in the epipharynx of the honey bee.

Taste-cups on the epipharynx of 
Panorpa debilis Westw?, and Boreus californicus Pack.-Having thus become in a degree familiar with the organs so clearly described and figured by Will, I was prepared to look for them in other insects. It was not until I had found them in the epipharynx of Panorpa and Boreus, that I was aware that other observers had already noticed them. In his historical summary Will states that G. Joseph ${ }^{2}$ in 1877 mentions that in almost all orders of insects, but especially in those living on plants, we find at the base of the tongue, in the region of the throat and the palate, little cups, which should be regarded as organs of taste. Künckel and Gazagnaire ${ }^{8}$ (188I) found in Volucella similar organs on the paraglossae (labella), on the end of the epipharynx and at the beginning as well as throughout the whole extent of the pharynx. Will does not seem to have seen the elaborate plates of these authors in the second part of their great work on Volucella, where the mouth-parts of Volucella ${ }^{4}$ are beautifully figured by Gazagnaire with numerous figures of microscopic sections of the proboscis and of the epipharynx and hypopharynx, including excellent histological details showing the gustatory

2Joseph, Gust. Zur morphologie des geschmacksorganes bei insekten. (A mtlicher bericht der 5o. Versammlung deutscher naturforscher u. Ärzte in München, 1877 , p. 227-228.)

3 Du siège de la gustation chez les insectes dipteres. Constitution anatomique et physiologique de l'épipharynx et l' hypopharynx. (Comptes rendus, r881, v.95, p. 347-35o.)

4 Recherches sur l'organization et le développement des diptères et en particulaire des volucelles de la famille des syphides, part I, 1875 , part $2.188 \mathrm{I}$, only the plates and their explanations. cups, cells and nerves. The taste-cups we have seen in the insects mentioned below are similar to those figured by Gazagnaire, and, judging by their appearance and position where the fluids enter the mouth, there seems little doubt that these pits or cups, with their projecting rods or fine setae are true organs of taste.

Our own observations are very superficial, no attempt having been made to study the parts histologically, or by microscopic sections, so as to work out the nerves and ganglion cells. We have simply dissected out the parts, placed them for a few minutes in a mixture of carbolic acid, I part, and oil of turpentine 4 parts, with a drop or two of dilute liquor potassae. This clears the parts, rendering them transparent, so that they can be at once placed in the animalculebox and examined under the microscope.

A word or two as to the homologies of the epipharynx may not be out of place. Little attention has been paid to the nature of this organ, and it is most desirable that a careful and comparative study of it be made. Morphologically it is the pharyngeal lining of the labrum and clypeus, and seems to be present in all insects. In the higher lepidoptera (macros) what has been regarded as the labrum is called by Dr. A. Walter ${ }^{5}$ the epipharynx. In the hymenoptera it forms a short fold situated under the projecting labrum. What in the mecaptera

\footnotetext{
o Walter, Alfred. Beiträge zur morphologie der schmetterlinge. Ier theil. Zur morphologie der schmet terlingsmundtheile. (Jena. zeitschr., 1885, v. 18, n. s., v. 9.)
} 
we call the parepipharynx is apparently the pale, non-chitinous, sensitive end of the labrum. It is in Panorpa a palatal fold or outgrowth, and in Boreus it is directly continuous with the labrum. For convenience, therefore, we will call this soft, non-chitinous, whitish highly sensitive fold projecting beyond the labrum the parepipharynx. And here it may be said that a very close relationship appears to exist between the parepipharynx of panorpidae and of the microlepidoptera, especially the tineidae, and in this point the panorpidae are quite unlike the neuroptera as restricted by Brauer and myself, which do not have a parepipharynx. In fact the parepipharynx appears to be mainly developed in the suctorial insects, such as the hymenoptera, lepidoptera and diptera, and also the mecaptera, but is not well developed in exclusively biting insects, which have the mandibles well developed.

Dr. Walter's figure and account of the labrum and epipharynx of Micropteryx semipurpurella is of special interest in connection with the structure of the homologous parts in Boreus. In the tineid in question, the five-sided or rather triangular, narrow, horny labrum is hollowed out at the end, the hollow being filled by the pale, sub-membranous p.repipharynx, which projects out from under the labrum and completes the apex of the triangle made by the two organs collectively. Now the labrum-epipharynx of Boreus and Panorpa, is rather long, narrow and triangular; in Panorpa the labrum ends in a corneous point, and the epipharynx forms two pale, membranous flaps on each side, as seen from above; in Boreus, however, the labrum ends in an obtuse point, and in fact appears at first as if hollowed out, as there are two dark thickened mandiblelike portions on each side of the labrum, free from setae and sensory pits. The parepipharynx forms a pale whitish, obtusely pointed projection of the end of the labrum, and is not, as in Panorpa, divided into lobes extending along the sides towards the base of the labrum.

I regard the structure of the labrumepipharynx of the mecaptera, and on the other hand the interesting discovery by Walter of the primitive lepidopterous maxilla of Micropteryx caltella with the lacinia (the homologue of one half of the "tongue") and the galea, besides the maxillary palpus, as very strong proof of the origin of lepidoptera from mecaptera-like forms. Walter does not state how nearly the shape of the galea of the Micropteryx in question corresponds to that of the true neuroptera (in sensu Brauer) but it is noticeable.

To return to the sense-organs developed in the labrum-epipharynx. The sensory organs are of two kinds $i . e$, taste-cups (Will) and taste-rods, besides tactile hairs and defensive setae, as well as what seem to be "gathering hairs" (Cheshire).

In Panorpa debilis? the labrum as seen from above is acutely triangular and edged with a single, slightly irregular row of long, stiff defensive setae which project a little beyond the edge of the epipharynx, both in front and on the 
side. In both the male and female on each side near the base of the epipharynx, is a group of about 20-25 taste-cups, each giving rise to a short hair. There are also scattered taste-cups near a point corresponding to the end of the labrum. On the upper side of the free edge of the epipharynx, there are scattered tastecups, varying in size, and like those already mentioned, though some of them are without perceptible hairs.

At the end of the epipharynx in the female are several gustatory pegs or rods; but in the male examined they seemed to be more numerous, there being a group of two short stout ones in the middle, one on each side of the median line of the body; and a group of four larger ones on each side of the central pair.

On the under side of the epipharynx there is a striking variety of hairs, differing much in character and variously grouped. Around the edge of the anterior division of the organ, there is a single row of very long, rather stout setae, apparently tactile, possibly both tactile and defensive. The edge, however, of the basal division of the epipharynx, is thickly fringed with long slender hair-like setae, flattened and triangular at the base. Three of the setae are larger than the others and spinulose. The greater part of the organ is free from hairs, there being only two groups near the middle of fine slender hairs which are flattened and broad at the base; these, like those fringing the edge of the basal division, in shape resemble the "gathering" hairs of the bee's proboscis, and are evidently for the purpose of collecting and amassing moisture, whether the saliva or the liquids entering the mouth, or both, we cannot say. These delicate gathering hairs, $i . e$, those which are very slender and flexible and arising from a flattened triangular base, as we have seen in Vespa maculata and Nematus erichsonii, line the pharynx, above and beneath, though of varying sizes and mode of grouping. Indeed, the epipharynx is simply a continuation and outgrowth of the roof of the mouth. The exact function of these hairs remains to be determined. They seem to be, so to speak, colossal chitinous cilia, serving at times to retain the saliva or liquid food in certain places, and in others to facilitate the passage of the food down the throat.

The labrum-epipharynx of Boreus californicus is quite different in shape from that of Panorpa; it is a little longer than broad, not dorsally separated by a distinct transverse suture from the clypeus, though laterally separated by a distinct notch. The labrum itself is not longer than broad, and not excavated in front, but on the contrary somewhat produced, extending into the base of the parepipharynx. Near the base at each side is a dark chitinous triangular thickening of the shape of a mandible, $\mathrm{bu}^{\mathrm{t}}$ not dentate at the end. Between the base of these mandible-like thickenings is a group of four taste-cups, protected on the inside by three defensive setae. On each side of the median line of the labrum, and extending back under what 
appears to be the end of the clypeus are two narrow thickenings of the surface, along which are scattered taste-cups, there being about 20 on each side of the median line. ${ }^{6}$ There is also a taste-cup on an area corresponding to the thin, front edge of the labrum, about midway between the most distal taste-cup, and the tip of the mandible-like thickening.

While the epipharynx of Panorpa scarcely projects beyond the acute end of the labrum, and is apparently divided into two large lateral divisions, and moreover is divided into a basal and distal portion (a somewhat significant fact in connection with the possibility that the labrum represents a pair of appendages) ; in Boreus the parepipharynx extends well beyond the end of the labrum, and shows no signs of a division into lateral or longitudinal lobes. It is a somewhat crescent-shaped whitish fold, tending in front of the labrum to a distance nearly half its width. There are no taste-cups on it, but around the edge a series of about 16 large taste-rods, which project as far as the marginal hairs situated between them. They are considerably, about twice, as long as those at the extremity of the epipharynx of Panorpa.

All of the hairs appear to be of the

6 It should be observed in view of the figures by Dr. W. Patten, Studies on the eyes of arthropods, Journ. morphology, July, 1888, v. 2, pl. 7, p. I-7, of the labrum of Acilius, which appears to answer to a pair of limbs representing a first pair of antennae; that in Boreus, besides the bilateral mandible-like thickenings the labrum also appears to be slightly divided along the middle by these two parallel ridges or thick. enings, giving rise to the appearance of an obsolete median suture. But this needs further examination. $\mathrm{k}$ ind denominated gathering hairs, and we do not appear to have the marked differentiation into different kinds of hairs and setae noticeable in the epipharynx of Panorpa. They are in Boreus arranged in about six curvilinear series; and are broad at the base, not triangular, but with parallel sides until in the middle they suddenly contract into hairs. They are probably neither specially tactile or protective, but rather adapted for gathering liquids and promoting their flow down the throat.

Taste-cups on the labium and maxillae of Panorpa.-In the same species ( $P$. debilis ?) I have noticed taste-cups on the labium in two regions; a group of five or six on the upper surface, on each side at the base of the first or basal joints, also a group of about a dozen on each side of a region including the base of the labium and end of the mentum. These taste-cups are characterized by having a short minute hair arising from the centre of the cup. They were observed in the male, but undoubtedly occur in the other sex, as I have not as yet observed any sexual distinctions in this group as regards the distribution either of gustatory or olfactory organs.

In the maxillae of the same species there are in both sexes a few taste-cups, protected by long defensive setae on the stipes near the base of the palpi ; and in the male I noticed a group of five such pits at the base of the lacinia, while others are scattered along the outer edge, near the base of the singular series of marginal comb-like sets of flattened, 
curved, scraping hairs. A few tastecups were also noticed scattered in a row along the outer edge of the galea of the female.

Taste-cups on the maxillae of Boreus californicus.-No taste-cups were observed on the labium of Boreus, which is very different in shape from that of Panorpa, unless four or five pits protected by two or three spines and situated at the base of the palpi are such. On the basal region of the galea of the maxillae, however, there is a series of taste-pits, the basal one the largest. No hair arises from the centre, and the pits are protected in front and on the outside by unusually short and stout peg-like defensive setae.

The structure of both the labium and maxillae of the mecaptera is very :ateresting, but space forbids our entering into farther details.

Olfactory rods on the palpi of Panorpa and Roreus.-At the end of the second or distal joint of the labial palpi of Panorpa is the usual pale area, bearing about $\mathrm{I} 8$ small short rods, which are probably olfactory; these are as usual roughly arranged in two series, and by groups. The last joint of the maxillary palpi bears olfactory rods of the size and number of those in the labial palpi. The end of the distal joint of the very short labial palpi of Boreus, is provided with about ten small olfactory rods which are slightly larger than those of the maxillary palpi.

The rather acute end of the maxillary palpi terminates in a pale clear space through which can be dimly seen the nerves leading to the seven or eight olfactory rods, which themselves are a little smaller than those of the labial palpi. Also at the distal end of the second joint are four sensory pits.

The olfactory pits of the antennae of Panorpa and Boreus.-In the terminal antennal joint of the female of Panorpathere are to be seen on one side about 35 olfactory pits scattered irregularly among the setae. In both sexes of Boreus, there are to be seen on one side of the last joint about eight olfactory pits, none at the end; on the penultimate joint there are on one side five pits, three in a row on one side, two on the other; the third and fourth joints from the end have two on the side next to the observer, the fifth and sixth one each.

Of course the exact function of these antennal pits is hypothetical until determined by repeated experiment; but provisionally they may be regarded as olfactory in their nature.

In conclusion we may say that by the use of the creosote and oil of turpentine mixture, the sense-organs can be easily examined superficially, and it is very fascinating work. It should, however, when possible, be supplemented by the preparation and examination of sections, after the most rigorous and exact histological methods, so as to reveal the nerves and ganglion cells of special sense.

The specimens of Boreus were kindly given me by Dr. A. Agassiz, Director of the Museum of Comparative Zoology, Cambridge, Mass. 

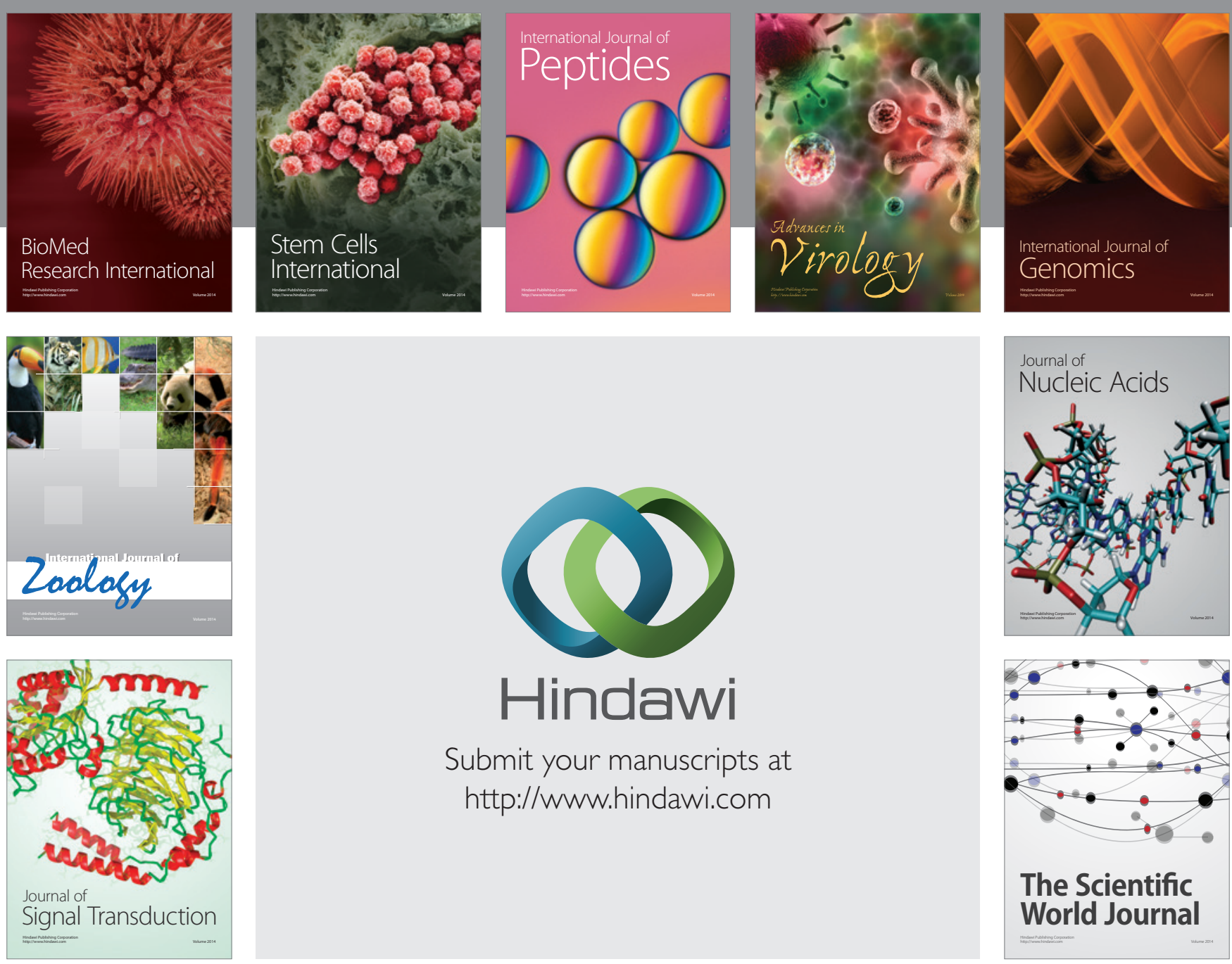

Submit your manuscripts at

http://www.hindawi.com
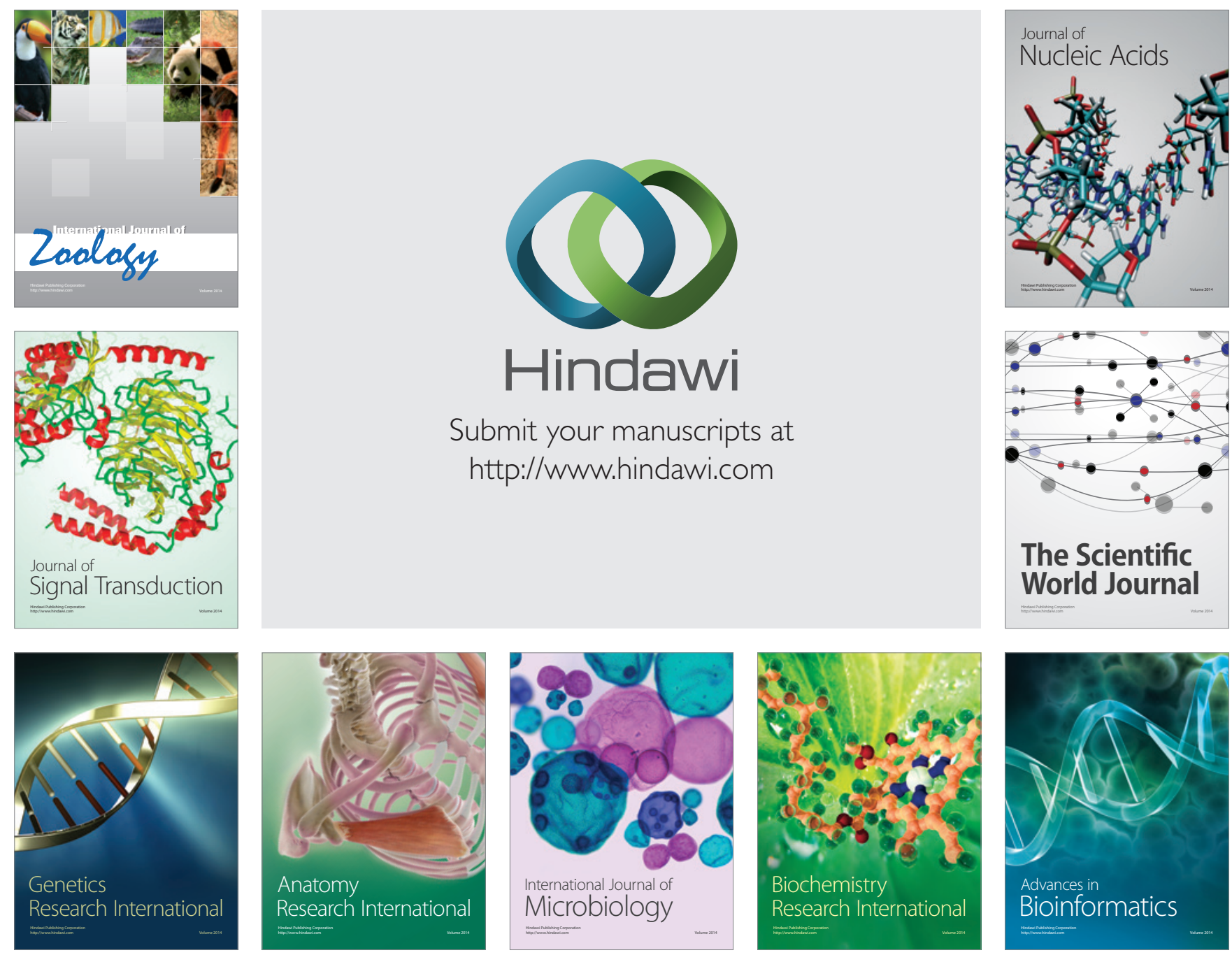

The Scientific World Journal
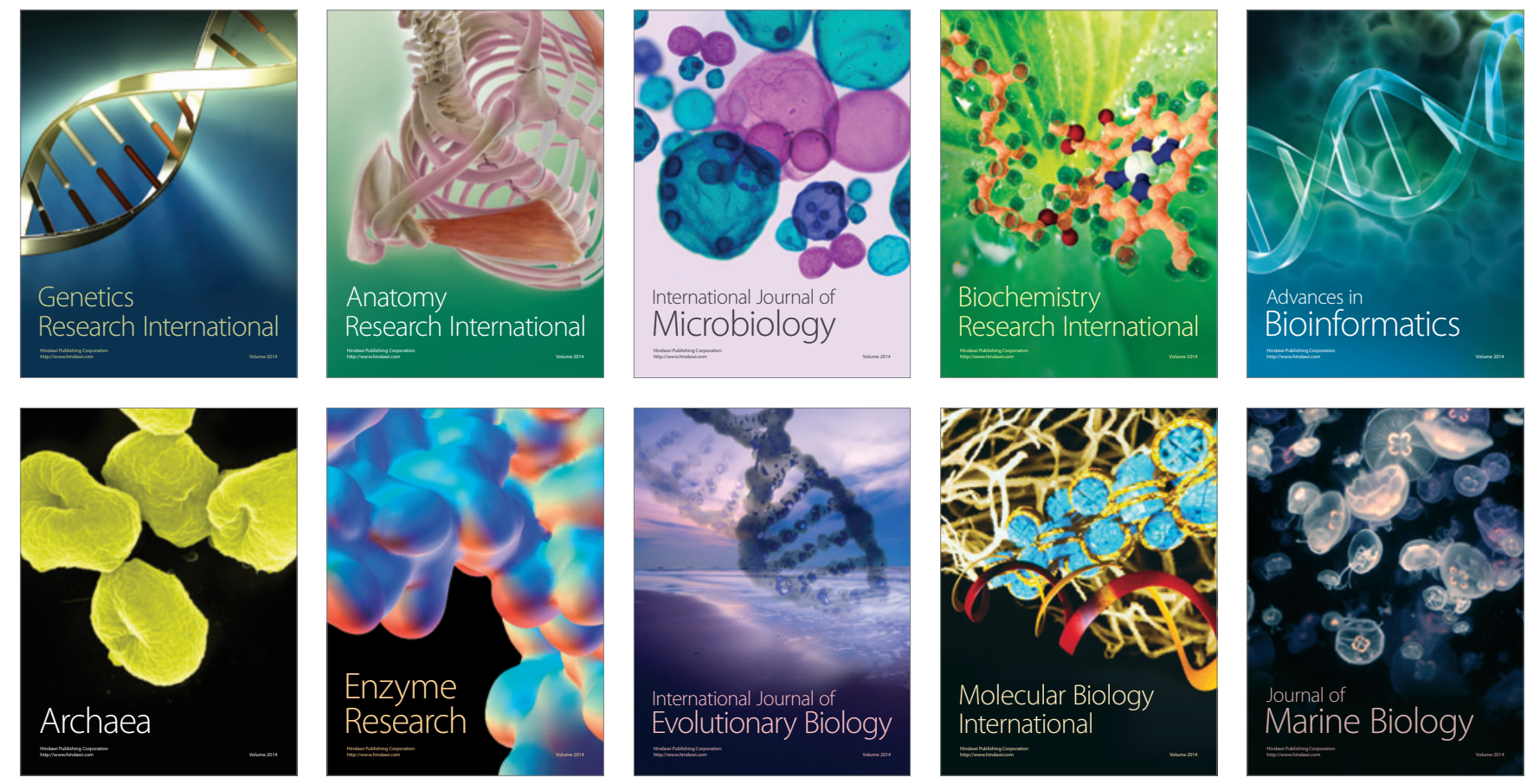